\title{
ANALISIS KRITIS TERHADAP KRISTOLOGI DALAM ISLAM
}

\author{
Adi Putra, Charisal B. S. Manu \\ Sekolah Tinggi Teologi Pelita Dunia Tangerang \\ addiepoetra7@gmail.com
}

\begin{abstract}
This study examines Islamic Christology. The aim is to reveal what Islam teaches about Jesus Christ because, in Islam, Jesus is also known as the prophet Isa. Using a qualitative method that focuses on literature review, it is hoped that it can reveal the nature of Christology in Islam to see its weaknesses and mistakes. The result is, Islamic Christology is a false and wrong Christology. They claim that Jesus is not God / Allah, Jesus is only a prophet, Jesus never dies, Jesus as the Son of God is heretical, even the teachings of the Trinity are also rejected. That is why through this research, it is concluded that Islamic Christology is a heretical Christology so that it cannot be used as a reference for learning and talking about Christ.
\end{abstract}

Keywords: Islamic Christology, Christian Christology, Bible, Al-Qur'an

\begin{abstract}
Abstrak. Penelitian ini meneliti tentang Kristologi Islam. Tujuannya untuk mengungkap seperti apa sebenarnya Islam mengajarkan tentang Yesus Kristus. Hal ini dimungkinkan karena memang dalam Islam juga mengenal Yesus sebagai nabi Isa. Dengan menggunakan metode kualitatif yang memusatkan pada kajian literatur, maka diharapkan dapat mengungkapkan natur kristologi dalam Islam guna melihat kelemahan dan kekeliruannya. Setelah diteliti, ternyata memang Kristologi Islam adalah kristologi yang sesat dan keliru karena di dalamnya mereka mengklaim Yesus bukan Tuhan / Allah, Yesus hanyalah nabi, Yesus tidak pernah mati, Yesus sebagai Anak Allah adalah sesat, bahkan ajaran tentang Trinitas juga ditolak. Itulah sebabnya, melalui penelitian ini disimpulkan bahwa kristologi Islam merupakan kristologi yang sesat sehingga tidak dapat dijadikan referensi untuk belajar dan berbicara tentang Kristus.
\end{abstract}

Kata Kunci: Kristologi Islam, Kristologi Kristen, Alkitab, Alquran

\section{PENDAHULUAN}

Kristologi atau ajaran tentang Yesus Kristus merupakan ajaran atau doktrin yang sentral dan penting dalam teologi Kristen. Doktrin tentang kristologi tidak hanya dipelajari dan dikaji oleh teolog Kristen, tetapi juga dipelajari dan 
dikaji dalam kalangan Islam. Ahwan Fanani mengatakan, "Tumbuhnya Kristologi dalam wacana pemikiran Islam populer di Indonesia dilatarbelakangi oleh berbagai persinggungan antara umat Islam dan Kristen yang diwarnai dengan sikap saling curiga dan antagonistik”.(Fanani, n.d.)

Masroor Library juga mempublis sebuah artikel yang berjudul Pentingnya Mempelajari Kristologi. Dalam artikel tersebut dikemukakan,

Di kalangan umat Islam, Kristologi adalah ilmu pengetahuan tentang kristianitas dalam arti agama yakni agama Kristen atau Nasrani. Kristologi ruang lingkupnya sangat luas karena mencakup ilmu pengetahuan tentang kitab suci atau bibel, iman Kristen atau dogmatika gereja, Trinitas, Roh Kudus, Yesus Kristus, Sakramen, Liturgia, Kerahiban, Nubuat, Dosa Waris dan penebusannya, dan sebagainya.("Pentingnya Belajar Kristologi" 2019)

Penjelasan di atas menunjukkan betapa cakupan Kristologi dalam Islam sangat luas. Tidak hanya mencakup tentang Kristus dan karya-Nya, melainkan meliputi seluruh ajaran dalam agama Kristen. Dengan demikian, ketika Islam belajar Kristologi mereka tidak dapat memisahkannya dari ajaran-ajaran Kristen yang lain, seperti: ajaran tentang Roh Kudus, dosa, Sakramen, dan lain-lain.

Menarik untuk memperhatikan apa yang dikemukakan oleh Kodiran Salim yang mengatakan, "Masih banyak umat Islam yang alergi mendengar istilah Kristologi, apalagi untuk mempelajarinya. Dalam hal ini, memang (sedikit) dimaklumi, lantaran istilah dan ilmu tersebut berkaitan dengan agama Kristen, sehingga ada kekhawatiran (apabila mempelajari Kristologi) bisa menyebabkan umat Islam menjadi Kristen (kafir)".(Salim 2012) Sekalipun demikian, Salim tetap memberikan saran supaya setiap umat Islam tetap mempelajari Kristologi, 
dan baginya itu adalah sesuatu hal yang lumrah bahkan penting. Selanjutnya Salim menyarankan bahwa metode yang digunakan berbeda dengan yang digunakan oleh orang Kristen pada umumnya. Karena Kristologi dalam Islam adalah Kristologi yang didasarkan pada Al-Quran, Hadist, sekaligus menjadi standar ujinya.(Salim 2012)

Menurut Wahju S. Wibowo, dalam seperempat Abad terakhir ini, ada kebangkitan kontekstualisasi teologi, khususnya kristologi yang berbicara mengenai Kristus dan penebusan dengan cara yang berbeda. Kristologi kontekstual seperti ini mendatangkan pengaruh besar pada refleksi tentang Yesus, dialog antar-agama dan kontekstualisasi iman.(Wibowo 2012)

Apabila memperhatikan apa yang dijelaskan oleh Salim dan membandingkan pendapat Wibowo perihal umat Islam belajar kristologi, sepertinya tidak mungkin Kristologi dapat dijadikan pintu masuk untuk terciptanya dialog antar agama, terutama karena sumber kajian Kristologi masingmasing agama berbeda sama sekali. Sehingga dapat diasumsikan bahwa kristologi Islam pasti sangat berbeda dengan rumusan kristologi dalam kekristenan.

Sepintas dapat diuraikan bahwa dalam Islam sendiri diperhadapkan kepada sebuah kesulitan untuk memahami Yesus Kristus sebagai Anak Allah. Oleh karena seperti yang dikemukakan oleh Waryono, bahwa penolakan Islam terhadap doktrin Kristen tentang anak Tuhan dalam al-Qur'an dinyatakan dalam kata walad (QS.al-Ikhlas [112]: 3), yang memilikikonotasi makna biologis, tapi dalam ayat lain dinyatakan juga dengan waharaqa lahu baniin (QS.al-An'am [6]:100), 
dimana haraqa berarti mengklaimnya secera dusta dan bohong (Waryono 2011). Berdasarkan penjelasan ini maka dapat dipastikan Kristologi Islam menolak pandangan Kristologi Kristen, khususnya pandangan Kristen yang menyebut Yesus sebagai Allah atau Anak Allah.

Problematika seperti inilah yang kemudian mendorong penulis untuk meneliti topik ini. Sehingga melalui penelitian ini dikaji seperti apa sebenarnya kristologi dalam Islam, kemudian melakukan evaluasi kepada pandangan tersebut. Oleh karena seperti yang telah dikemukakan pada bagian awal bahwa ajaran tentang Kristus merupakan yang penting dan inti bagi iman Kristen. Dengan demikian, penelitian ini berusaha menyajikan data ilmiah dengan kajian literature khususnya literatur Kristen untuk menunjukkan kekurangan dan kelemahan dari pandangan Kristologi dalam Islam.

\section{METODE PENELITIAN}

Pada penelitian ini menggunakan penelitian kualitatif dengan berfokus kepada kajian kepustakaan. Menurut Lexy J. Moleong, penelitian kualitatif menggunakan metode kualitatif yaitu pengamatan, wawancara, atau penelaahan dokumen. Biasanya metode kualitatif ini digunakan karena beberapa pertimbangan. Pertama, menyesuaikan metode kualitatif lebih mudah apabila berhadapan dengan kenyataan jamak. Kedua, metode ini menyajikan secara langsung hakikat hubungan antara peneliti dan responden. Ketiga, metode ini lebih peka dan lebih dapat menyesuaikan diri dengan banyak penajaman pengaruh bersama pola-pola nilai yang dihadapi (Moleong 2010). Ditambahkan oleh 
Moleong, dengan menggunakan analisis secara induktif, berarti setiap upaya pencarian data bukan dimaksudkan untuk membuktikan hipotesis yang telah dirumuskan sebelum penelitian diadakan. Analisis ini lebih merupakan pembentukan abstraksi berdasarkan bagian-bagian yang telah dikumpulkan, kemudian dikelompok-kelompokkan. (Moleong 2010).

Sementara, kajian kepustakaan dimaksudkan untuk mengkaji pandangan Islam tentang Kristologi dengan data atau informasi dari literatur-literatur yang terkait. Dengan demikian, dalam penelitian ini penyusunan teori berasal dari bawah ke atas (grounded theory) yaitu dari sejumlah data yang banyak dikumpulkan dan saling berhubungan. Setiap literatur yang digunakan dalam penelitian ini terkait dengan Kristologi baik dari perspektif Islam, yang selanjutnya dianalisis dan dikritisi

\section{HASIL PENELITIAN}

\section{Kristologi dalam Islam}

Kristologi dalam Islam dapat juga disebut sebagai kritik terhadap paham kristologi yang ada dalam ajaran Kristen. Secara fundamental, Islam menolak dan menganggap keliru pandangan Kristen tentang Tuhan, yang menegaskan bahwa Tuhan itu memiliki anak (biogetisme). Selain itu, kelompok Islam juga menolak ajaran Trinitas, yang dalam pandangan mereka telah menodai keesaan Allah (Waryono 2011). Dalam hubungannya dengan Kristologi, maka berikut ini diuraikan secara spesifik. 
Kristus bukan Allah. Seperti yang dikemukakan oleh Waryono, bagi umat Islam, Isa yang disebut 24 kali dalam Alquran, yang penyebutannya sering menggunakan kata Ibnu Maryam, adalah tidak lebih sebagai manusia biasa yang lahir dari seorang wanita dan tidak memiliki sifat ketuhanan (divinity). Bagi Islam, Isa adalah seorang nabi (QS. Maryam [19]: 30) dan juga seorang rasul (QS. Ali Imran [3]:45) dan termasuk dalam deretan rasul-rasul lain.(Waryono 2011)

Penolakan Islam terhadap keilahian Yesus tentunya sejalan dengan pandangan mereka yang juga menolak konsep Anak Allah yang merupakan salah satu gelar yang diberikan kepada Yesus Kristus dalam ajaran Kristen. Selain itu, pandangan Yesus bukan Allah juga berkaitan erat dengan sikap Islam yang menolak ajaran Trinitas. Karena dalam ajaran Trinitas, Yesus Kristus merupakan pribadi kedua dari Allah Tritunggal.

Bagi Islam, julukan yang diberikan oleh orang Kristen kepada Yesus sebagai "Putra Allah" dan "Bunda Allah" kepada Maria dianggap oleh umat Muslim sebagai penghujatan kepada Allah. Bahkan Yesus sendiri menolak tuduhan bahwa Dia sendiri menamakan diri-Nya Allah. Pendapat Islam ini tertulis dalam Al Maaidah: 116-117, yang bunyinya sebagai berikut:

"Dan (ingatlah) ketika Allah berfirman: Hai Isa putra Maryam, adakah kamu mengatakan kepada manusia: Jadikanlah aku dan ibuku dua orang tuhan selain Allah?. Isa menjawab: Maha suci Engkau, tidaklah patut bagiku mengatakan apa yang bukan hakku (mengatakannya). Jika aku pernah mengatakannya, maka tentulah Engkau mengetahuinya. Engkau mengetahui apa yang ada pada diriku dan aku tidak mengetahui apa yang ada pada diri Engkau. Sesungguhnya Engkau maha mengetahui perkara yang gaib-gaib. Aku tidak pernah mengatakan kepada mereka kecuali apa yang engkau perintahkan kepadaku (mengatakan)nya yaitu: sembahlah Allah, Tuhanku dan Tuhanmu' dan adalah aku menjadi saksi terhadap 
mereka, selama aku berada diantara mereka. Maka setelah Engkau wafatkan aku, Engkaulah yang mengawasi mereka. Dan engkau adalah maha menyaksikan atas segala sesuatu". (Troll 2013, 14,17)

Dengan demikian dapat dilihat bahwa penolakan Islam terhadap keilahian Yesus dikarenakan mereka berasumsi bahwa Yesus hanyalah nabi. Pandangan seperti ini didasarkan kepada bukti-bukti yang terdapat dalam Alquran, di mana diasumsikan bahwa Yesus sendiri menolak telah mengakui dan mengklaim dirinya sebagai Allah atau Tuhan. Itulah sebabnya, bagi orang Islam, pribadi dan peranan Yesus telah dilebih-lebihkan oleh orang Kristen. Bahkan ketika orang Kristen meng-Allah-kan Yesus Kristus, maka hal itu dianggap sebagai penyembahan berhala.

Penyaliban Kristus dan Kurban Pengganti. Penolakan Islam terhadap penyaliban Kristus dalam kaitannya dengan dosa warisan. Bagi Islam manusia lahir dalam keadaan suci dan tidak menanggung atau membawa dosa. Manusia hanya bertanggung jawab terhadap apa yang telah diperbuatnya dan menjadi tanggungjawabnya. Bahkan bagi Islam, orang tidak bisa mengalihkan tanggung jawabnya, juga tidak bisa mengorbankan orang lain untuk mempertanggungjawabkan perbuatan yang telah dilakukannya. Atas dasar itulah, Islam menolak penyaliban Kristus (QS.an-Nisa' [4]:157).(Waryono 2011)

Bey Arifin mengatakan, "Akan tetapi menurut Islam, bukan Yesus yang dinaikkan ke tiang salib, tetapi adalah orang lain yang diserupakan Allah menjadi wajah Yesus, sedangkan Yesus sendiri pada waktu itu telah dinaikkan oleh Tuhan ke langit". (Arifin 1983, 89) 
John R.W. Stott juga menegaskan bahwa Islam menolak penyaliban Yesus. Karena dalam pandangan Islam, tidak sepatutnya seorang nabi Allah yang besar mengakhiri hidupnya dengan cara yang sedemikian memalukan. Alquran tidak melihat adanya kebutuhan akan kematian seorang juruselamat yang menanggung dosa (Stott 2015). Bahkan menurut Stott, setidaknya lima kali Alquran menyatakan secara absolut dan eksplisit, bahwasanya seorang yang berdosa tidak akan memikul dosa orang lain. Termasuk, jika seorang yang berat dosanya memanggil (orang lain) untuk memikul dosa itu, tiadalah akan dipikulkan untuk sedikitpun meskipun yang dipanggil itu kaum kerabat.(Stott 2015)

Selain menolak kebutuhan akan salib, Islam (Alquran) juga bahkan menyangkal fakta peristiwa salib. Bahkan menuduh orang Yahudi telah mengucapkan dusta besar ketika mengklaim telah membunuh $\mathrm{Al}$ masih, Isa putra Maryam, Rasul Allah. Padahal dalam Alquran dicatat bahwa mereka tidak membunuhnya dan tidak (pula) menyalibkannya.. Mereka tidak mempunyai keyakinan tentang siapa yang dibunuh itu, kecuali mengikuti persangkaan belaka. Jadi seperti yang dikemukakan oleh Bey Arifin di atas, bahwa Islam meyakini bahwa Allah telah menyihir para musuh Yesus untuk menyelamatkan Dia, dan bahwa entah Yudasa Iskariot atau Simon dari Kirene yang menggantikan Dia pada saat terakhir. (Stott 2015)

Berbeda lagi dengan sekte dalam Islam, yakni Ahmadiyah yang pada abad ke-19 dengan meminjam gagasan dari kelompok Kristen Liberal mengatakan bahwa Yesus hanya pingsan di atas salib, dan siuman di dalam kubur, dengan 
menambahkan bahwa sesudah itu Dia pergi ke India untuk mengajar, dan mati di sana; mereka bahkan mengklaim sebagai penjaga kubur Yesus di Kashmir.(Stott 2015)

Berdasarkan uraian di atas, maka dapat dilihat dengan jelas bahwa penolakan Islam terhadap penyaliban Yesus Kristus didasarkan pada bukti-bukti tertulis dalam Alquran. Di mana pada intinya bahwa mereka tidak hanya menolak kebutuhan penyaliban (Yesus sebagai kurban pengganti dan menolak dosa warisan), namun juga menolak peristiwa salib itu sendiri. Oleh karena bagi mereka, yang disalib bukanlah Yesus; Allah telah menggantinya dengan orang lain. Namun kemudian pandangan ini berkembang terutama dalam kelompok Ahmadiyah yang seolah-seolah menyatakan bahwa memang Yesus yang disalib namun Dia tidak mati atau hanya pingsan. Sehingg ketika sampai dalam kubur, Dia kemudian siuman lalu pergi ke India untuk mengajar. Bahkan bagi mereka, Yesus juga mati dan dikubur di India.

Perjalanan Yesus ke India pasca-tersadar dari pingsannya juga dibenarkan oleh Djuyoto Suntani yang mengatakan bahwa pada kalangan masyarakat Kashmir, India, telah menemukan makam "asing" berukuran panjang yang diyakini sebagai makam Yesus Kristus. Kemudian beberapa ahli juga yang meyakini bahwa separoh kehidupan Yesus dijalaninya di wilayah India sampai meninggal dan dikuburkan di Kashmir, semakin diyakini oleh kaum intelektual dan masyarakat rasional Barat (Suntani 2001). 
Bahkan berdasarkan Surat Ali Imran: 44 yang berbunyi, “Tatkala malaikat berkata: Wahai Maryam, sesungguhnya Allah memberi kabar baik kepada engkau dengan firmannya (tentang seseorang) yang namanya Isa Almasih bin Maryam, yang dihormati di dunia dan akhirat dan tergolong orang dekat (kepada Allah)", maka memberikan bukti yang menegaskan bahwa Isa atau Yesus melakukan dakwah hingga dia meninggal pada usai lanjut (tua) (Suntani 2001). Dengan demikian hal inipun menolak fakta tentang peristiwa penyaliban dan salib seperti yang terdapat dalam Alkitab.

Artinya, kelompok Islam tidak hanya menolak penyaliban saja, tetapi juga menolak kematian bahkan secara tidak langsung juga menolak kebangkitan Yesus. Di mana peristiwa yang terakhir merupakan peristiwa yang sangat penting bagi iman Kristen.

Inkarnasi Kristus. Khusus untuk ajaran inkarnasi ditolak oleh Islam karena memang pada prinsipnya Islam menolak keilahian Yesus, juga menolak konsep Anak Allah, bahkan juga menolak konsep penebusan dalam Kristus untuk menggantikan manusia berdosa.

Abdullah Syarqawy menjelaskan pandangan seorang pemikir atau teolog besar dalam Islam, yakni Al-Ghazali. Bagi Al-Ghazali, Al-lahut wa an-Nasut (Kodrat Ketuhanan danKemanusiaan) harus dibatalkan. Karena ketika mereka (orang Kristen) berkeyakinan bahwa Tuhan menjadikan Isa as, mempunyai sifat ketuhanan (al-Lahut), kemudian Tuhan menjelma di dalam diri Isa as. (an-Nasut) 
dan menyatu. Mereka (orang Kristen) bermaksud menunjukkan al-Ittihad (union substantion/penyatuan) seperti penyatuan jiwa dan raga (Syarqawy 1994).

Bahkan dilanjutkan oleh Al-Ghazali bahwa akibat dari pada penyatuan itu kemudian menimbulkan hakikat yang ketiga, yang sama sekali berlainan dengan hakikat diantara masing-masing, yaitu hakikat Tuhan dan hakikat Isa as. Apabila terdapat asumsi bahwa hakikat yang ketiga, yang terdiri dari unsur Lahut dan Nasut, di mana diantara kedua sifat tetap berdiri pada posisi sifat masing-masing dalam arti Lahut sebagai Tuhan dan Nasut sebagai manusia, maka keberadaan hakikat ketiga merupakan ungkapan yang runtuh dan bodoh (Syarqawy 1994).

Penolakan Islam terhadap inkarnasi Yesus dapat dikatakan berangkat dari pemahaman mereka kepada transendensi Allah. Yang maksudnya hendak menegaskan bahwa Allah sungguh berbeda dari ciptaan-Nya. Kelompok Islam tidak bisa menerima segala upaya manusia untuk mengasosiasikan, menyamakan (syirik) atau mengasimilasikan (tasbih) sebuah benda atau makhluk ciptaan dengan Allah. Sikap ini sejalan dengan pandangan Alquran yang secara tegas dan berulang-ulang mengutuk usaha seperti itu (Troll 2013). Itulah sebabnya, Islam dengan keras menolak ajaran inkarnasi Yesus, karena adalah mustahil Allah dapat masuk dan menjadi bahkan menjelma menjadi ciptaan.

Kesimpulan. Berdasarkan uraian panjang-lebar di atas, maka dapat simpulkan sebuah rumusan kristologi dalam Islam. Di mana secara gamblang menggambarkan sebuah kristologi yang menolak kristologi Alkitab. Islam melalui kesaksian Alquran menjelaskan bahwa Yesus hanyalah seorang nabi, dia bukanlah 
Allah yang berinkarnasi, karena bagi mereka tidak mungkin Allah yang adalah pencipta dapat masuk dan menjadi sama dengan ciptaan. Kemudian Yesus memang pernah disalibkan, namun kemudian ditolong oleh Allah dengan menggantikannya dengan oknum lain. Sehingga Yesus dapat berdakwah hingga usia tua bahkan meninggal pada saat lanjut usia di wilayah India, tepatnya Kashmir. Sebagai catatan, kristologi yang Islam tawarkan ini sangat bertolak belakang dengan kristologi dalam Alkitab atau yang diajarkan dalam agama Kristen.

\section{Analisis Kritis Kristologi dalam Islam}

Berikut ini akan diuraikan evaluasi terhadap kristologi dalam Islam yang didasarkan pada penjelasan dan uraian di atas. Pertama, Kristologi Islam hanya melihat Yesus sebatas nabi saja. Itulah sebabnya dalam waktu yang bersamaan Islam juga menolak ajaran Yesus adalah Anak Allah (karena bagi mereka Allah tidak mungkin beranak dan diperanakkan) dan juga menolak ajaran Trinitas. Semua pendapat di atas, didasarkan kepada bukti tertulis dalam Alquran.

Kedua, Kristologi dalam Islam adalah kristologi yang melihat Yesus tidak pernah mengalami kematian, sekalipun Dia disalibkan namun Allah menolongNya dengan menggantikan dengan oknum yang berbeda. Dengan demikian, pandangan ini sekaligus menegasi ajaran tentang kebangkitan Yesus. Bahkan bagi Islam mengajarkan bahwa setelah Yesus berhasil selamat dari hukuman 
penyaliban maka Dia pergi ke India dan mengajar di sana (kemungkinan juga menikah) hingga usia lanjut (tua) dan akhirnya dimakamkan di sana.

Ketiga, Kristologi dalam Islam adalah kristologi yang menolak inkarnasi. Oleh karena dalam doktrin Islam, Allah yang adalah pencipta tidak mungkin menjadi manusia (ciptaan).

Pandangan Kristologi Islam seperti yang tergambar dalam penjelasan tiga poin di atas terlihat jauh berbeda bahkan kontradiksi dengan ajaran Alkitab tentang Kristologi. Terlihat Islam mengalami kegagalan dalam merumuskan sebuah konsep kristologi dan justru menggunakan Alquran sebagai sumber informasi, padahal Alquran memiliki informasi yang keliru tentang Kristologi bahkan bukanlah merupakan sumber informasi yang valid untuk belajar kristologi.

Islam harusnya menggunakan Alkitab sebagai sumber primer dalam membangun Kristologinya. Sekalipun memang hal ini merupakan hal yang mustahil karena Islam telah memiliki Alquran dan bagi mereka Alquran jauh lebih berotoritas dari pada Alkitab. Akan tetapi, akhirnya melahirkan sebuah rumusan kristologi yang tidak alkitabiah dan cenderung hanya asumsi bahkan spekulatif belaka.

Pada bagian berikutnya, akan diuraikan pandangan kristologi Alkitab yang menjadi pembanding terhadap kristologi Islam sekaligus menjadi acuan dasar untuk menegaskan betapa kelirunya pandangan kristologi yang terdapat dalam ajaran Islam. 


\section{PEMBAHASAN}

\section{Kajian Kristologi Menurut Alkitab Sebagai Model Kristologi yang Ideal untuk}

\section{Mengkritisi Kristologi Islam}

Berikut ini akan diuraikan beberapa ajaran Alkitab sekaligus menjadi ajaran kristologi Kristen yang jelas bertentangan dan bertolak belakang dengan kristologi Islam. Bahkan melalui penjelasan dalam bagian ini menunjukkan bahwa kristologi Islam adalah kristologi yang keliru dan hanya sekadar asumsi atau spekulasi belaka.

Pertama, kristologi yang benar mengajarkan Yesus adalah Allah dan Anak Allah. Ajaran dalam kekristenan sangat meyakini bahwa Yesus Kristus adalah Allah. Itulah sebabnya, dalam kekristenan juga meyakini bahwa Yesus adalah kekal adanya. Dia tidak memiliki awal dan tidak memiliki akhir, dan Dia bukanlah ciptaan. Dia sudah ada sebelum dunia diciptakan, bahkan akan terus ada dan sampai selama-lamanya akan tetap ada. Dia tidak dicipta karena Dia sejatinya adalah pencipta.

Seperti yang termaktub dalam Yohanes 1:1, "Pada mulanya adalah Firman; Firman itu bersama-sama dengan Allah dan Firman itu adalah Allah". Ayat ini dapat dibagi ke dalam tiga bagian; di mana ketiga-tiganya menekankan tentang pra-eksistensi Yesus. Seperti: Yesus sudah ada sejak semula, Yesus bersama-sama dengan Allah Bapa, dan Yesus sendiri juga adalah Allah (pribadi kedua dalam doktrin Allah Tritunggal). Ada tiga ungkapan atau frasa dalam ayat ini yang 
BONAFIDE: Jurnal Teologi dan Pendidikan Kristen

www.jurnal.sttissiau.ac.id/Volume 2/Nomor 1/Juni 2021/hal. 1-24

merujuk kepada pra-eksistensi Yesus. Ketiga ungkapan itu adalah en arkhē (pada mulanya), èn (ada/adalah), dan theos èn ho logos (Firman itu adalah Allah). En arkhe atau seringkali diterjemahkan dengan in the beginning atau pada mulanya pertama kali muncul dalam Kejadian 1:1 dalam konteks penciptaan langit dan bumi.(Putra 2019)

Verba $\bar{e} n$ yang merupakan bentuk indikatif imperfek dari eimi hendak menegaskan eksistensi Firman (Yesus) yang telah ada sejak kekekalan dan akan terus ada hingga kekekalan (tidak berakhir). Eksistensi-Nya sudah ada jauh sebelum Allah menciptakan langit dan bumi, karena Yesus tidak diciptakan. Oleh karena berdasarkan kata kerja ini Firman itu tidak berawal - Dia tidak diciptakan. Karena sejak semula Firman itu sudah ada. Dengan demikian hal memberikan penekanan bahwa Yesus adalah Allah.

Yesus Kristus adalah Allah sejati yang telah menjadi manusia sejati. Dia kemudian dikenal sebagai Anak Allah. Dalam Kristologi Islam memahami keliru ungkapan "Anak Allah" dengan menuduh bahwa kekristenan (Alkitab) mengajarkan bahwa Allah beranak. Apakah benar kekristenan mengajarkan demikian? Tentunya tuduhan ini adalah sebuah kekeliruan. Karena kekristenan tidak memahami konsep Anak Allah seperti itu. Lalu bagaimana kekristenan memahami konsep Anak Allah?

Untuk menolak dan melawan kristologi Islam yang keliru, maka perlu dijelaskan satu ungkapan yang juga digunakan oleh Injil Yohanes, yakni istilah monogenēs. Istilah ini muncul dalam Yohanes 1:14; 1:18; 3:16; dan 3:18. J. 
Ramsey Michaels mengemukakan bahwa ungkapan monogenēs sepadan dengan ungkapan agapetos dalam Injil Sinoptik. Penggunaan istilah monogenēs dalam Injil Yohanes hendak menegaskan relasi yang unik antara Yesus Kristus dengan Allah Bapa. Di mana relasi itu tidak harus berada dalam konteks hubungan secara metafisik atau diperanakkan, karena bukan makna itu yang hendak ditekankan oleh istilah monogenēs. Kata bentukan monogenēs dipakai untuk menggambarkan keunikan relasi antara Allah dan Yesus Kristus; bahwa Yesus adalah sama dengan Allah (Michaels 2010).

Hal yang serupa juga dikemukakan oleh Andreas J. Kostenberger dengan mengatakan, pengantar Injil Yohanes merujuk pada Yesus sebagai monogen atau 'Anak satu-satunya' dari Bapa (Yohanes 1:14) dan menekankan hubungannya yang unik dengannya (1:18). Bahkan ditambahkan oleh Kostenberger, karenanya, monogenes berarti dalam segala kemungkinan, bukan 'anak yang diperanakkan' tetapi 'anak yang unik' (Köstenberger 2009).

Berdasarkan istilah monogenēs yang digunakan penulis Injil (Yohanes) untuk menjelaskan tentang relasi Allah Bapa dengan Yesus Kristus sebagai Anak Allah, tidaklah tepat untuk memahami dalam relasi metafisik, melainkan dalam relasi yang unik. Sehingga pandangan dan ajaran kristologi Islam jelas keliru dan tidak dapat dibenarkan.

Bahkan Wayne Grudem menambahkan,

"The New Testament, in hundred of explicit verses that calls Jesus "God" and "Lord" and use a number pf other titles of deity to refer to him, and in many passages that attribute actions or words to him that could only be 
true of God himself, affirms again and again to full, absolute deity of Jesus Christ" (Grudem 1994).

Itulah sebabnya, bukti Alkitab tentang keilahian Yesus begitu melimpah. Sehingga apabila dikemudian hari terdapat ajaran yang bertolak belakang dengan ajaran Alkitab (khususnya dalam hal Kristologi), maka itu berarti ajaran kelompok tersebut tidak alkitabiah, tidak valid, sekalipun yang dikemukakan merupakan salah satu topik yang terdapat dalam Alkitab.

Kedua, kristologi yang benar mengajarkan bahwa Yesus disalibkan, mati, dan bangkit, bahkan Dia juga adalah kurban pengganti. Alkitab telah memberitakan dan mengajarkan bahwa Yesus benar-benar telah mati disalib untuk menggantikan manusia yang berdosa. Tidak hanya itu, karena Alkitab juga mengajarkan bahwa Yesus benar-benar telah bangkit (dibangkitkan), sesuai dengan ajaran Kitab Suci.

Ajaran tentang salib, penderitaan dan kematian Yesus memang merupakan ajaran yang penting dalam Kristologi. Itulah sebabnya, Alister E. McGrath mengatakan, "The cross as the place where God and Man meet, the cross as the demonstration of Man's Sin, the cross as the demonstration of God's love, and the cross as a decision" (McGrath 1997). Itulah sebabnya, tidak mungkin ada sandiwara pada peristiwa salib seperti yang dituduhkan dalam kristologi Islam. Yesus pergi menuju salib secara sukarela dan mati secara sukarela. Hal ini juga dibenarkan oleh John Stott. Bahkan dia juga menambahkan, natur kematian Yesus yang bersifat sukarela, mereka beberapa kali menggunakan kata kerja spesifik (paradidōmi) yang digunakan oleh para penulis kitab-kitab Injil untuk 
mengungkapkan bahwa Ia 'diserahkan' kepada kematian oleh orang-orang lain (Stott 2015).

Dengan demikian, substansi kristologi Kristen adalah Yesus benar-benar telah mati secara sukarela. Di mana naturnya dapat dilihat untuk menggantikan (substitusi) orang-orang berdosa, dan itulah sebabnya dikatakan bahwa Yesus rela mati demi dosa orang lain. "Keempat Injil mencakup fakta bahwa Yesus menyerahkan nyawa-Nya atau menghembuskan nafas terakhir-Nya. Ini berarti bahwa Dia bersedia untuk mati” (Peterson 2018, 69). Artinya, Yesus tidak hanya bersedia untuk mati tetapi Dia juga benar-benar mati seperti yang telah disaksikan oleh keempat Injil kanonik.

Apabila Yesus benar-benar mati, maka ketika Dia bangkit itu merupakan peristiwa yang faktual alias bukan sebuah sandiwara atau rekayasa. Yesus bangkit pada hari yang ketiga sesuai dengan nubuat dan kesaksian Kitab Suci untuk memberikan kemenangan bagi umat-Nya. Sama halnya dengan peristiwa kematian-Nya, peristiwa kebangkitan Yesus juga dicatat pada semua Injil. Peterson menambahkan, "Kematian dan kebangkitan Kristus begitu esensial bagi kekristenan dan tidak terpisahkan, sehingga jika Alkitab berbicara tentang salah satu dari keduanya, kita harus mengingat yang lain juga".Ibid, 143. Artinya, kedua peristiwa ini sama-sama penting dan saling terkait satu sama lainnya. Oleh karena apabila Yesus tidak benar-benar mati, maka kebangkitan-Nya juga adalah sesuatu rekayasa. Sebaliknya, apabila Yesus benar-benar mati, maka kebangkitanNya menjadi sangat berdampak bagi iman Kristen. Itulah sebabnya dalam 1 
Korintus 15, Paulus menegaskan tentang kebenaran kedua peristiwa ini. Bahkan Paulus menegaskan bahwa kebangkitan Yesus diperlukan bagi keselamatan kita sama seperti penyaliban-Nya. Joel R. Beeke memberikan komentarnya tentang uraian Paulus tentang kebangkitan Yesus pada 1 Korintus 15. Baginya, ide Paulus tentang iman, yaitu iman yang mendocking orang-orang berdosa dengan Kristus. Di tengah-tengah kegelapan dan keputusasaan dosa, kita melihat kepada Kristus dan mendocking pada-Nya oleh iman. Sebagai akibatnya, dan semua kebenaran dan pekerjaan baik-Nya datang melalui saluran iman dan diperhitungkan sebagai milik kita (Beeke 2020).

Sebagai tambahan, Yesus juga tidak pernah melakukan perjalanan misi ke India seperti yang termaktub dalam kristologi Islam. Oleh karena pascakebangkitan-Nya, Yesus naik ke surga supaya Roh Kudus datang untuk menjadi penolong bagi setiap pengikut-Nya supaya mereka tetap bertahan dalam penganiayaan di dunia.

Ketiga, kristologi yang benar mengajarkan bahwa Yesus adalah Allah yang berinkarnasi dan Dia adalah Pribadi Kedua dalam Allah Tritunggal. Seperti diketahui bersama, bahwa istilah trinitas dan inkarnasi memang tidak ditemukan dalam Alkitab. Akan tetapi perlu digarisbawahi bahwa kedua istilah ini sangat berguna dan merupakan istilah yang tepat bagi setiap orang Kristen untuk mendeskripsikan tentang ajaran Alkitab tentang Kristus (kristologi).

Oleh karena tugas-Nya sebagai pengantara, maka Yesus diharuskan menjadi manusia supaya Dia dapat menyelamatkan orang-orang berdosa. Sebagai 
pengantara dan juruselamat, Yesus secara natur adalah Allah yang sejati, karena hanya Allah yang dapat menyelamatkan manusia. Kemudian Yesus juga harus memiliki natur manusia sejati, karena keselamatan juga harus dilakukan oleh seorang manusia untuk manusia (Beeke 2020).

Berdasarkan penjelasan di atas, maka dapat dilihat bahwa inkarnasi Yesus merupakan sebuah keharusan karena bertujuan untuk menyelamatkan. Jadi, apakah Yesus benar-benar telah menjadi manusia atau berinkarnasi? Jawabannya adalah Yesus benar-benar telah menjadi manusia, karena Alkitab mengajarkan demikian. Itu berarti ada natur yang ditambahkan kepada diri-Nya, yaitu natur manusia. Lalu seperti apa memahami kemanusiaan Yesus?

William B. Evans mengatakan, Tentu saja Yesus memang telah datang untuk hidup di dalam dunia yang telah terjatuh. Ia mengalami penderitaan, pencobaan, dan kematian. Kemenangannya atas pencobaan adalah nyata. Ia dibuat sempurna dengan penderitaan (Ibr. 2:10), dan Ia belajar taat dari apa yang telah diderita-Nya (Ibr. 5:8). Dengan kata lain, Kitab Suci memang menekankan bahwa Kristus dalam segala harus disamakan dengan saudara-saudara-Nya (Ibr. 2:17), dan sebagai Adam kedua, Ia telah menang ketika Adam pertama gagal (lihat Rm. 5:12-21). Akan tetapi, kita juga harus menyadari bahwa bahasa tentang kemanusiaan Kristus yang berdosa dan telah terjatuh ini bersifat provokatif dan pada akhirnya tidak membantu (Evans 2020).

Berdasarkan penjelasan di atas dapat terlihat bahwa pada waktu berinkarnasi, Yesus benar-benar telah menjadi manusia sejati, manusia yang 
mengalami apa yang dialami oleh manusia pada umumnya, seperti: penderitaan, pencobaan, bahkan kematian. Akan tetapi satu hal yang membedakan adalah Yesus satu-satunya manusia yang tidak berdosa. Hal ini dimungkinkan karena manusia sejak dalam kandungan disebut dan diajarkan oleh Alkitab oleh karya Roh Kudus. Status ketidakberdosaan inilah yang memungkinkan diri-Nya dapat mengerjakan misi-Nya untuk mati menggantikan manusia demi keselamatan mereka.

Robert Letham mengatakan, "Inkarnasi Anak menunjukkan bahwa distingsi-distingsi dari pribadi-pribadi itu tidak dapat direduksi. Hanya Anak yang berinkarnasi dan sekarang disatukan dengan kemanusiaan. Bapa maupun Roh Kudus tidak secara pribadi disatukan dengan manusia... Sementara hanya Anak yang telah menjadi manusia, inkarnasi bagaimanapun menyatakan keseluruhan Trinitas" (Letham 2011, 409-10).

Kitab-kitab Injil juga memberikan kesaksian yang gamblang tentang inkarnasi sekaligus ajaran Trinitas dalam berbagai kesempatan. Misalnya, dalam doa-doa yang Yesus sampaikan kepada Bapa menyatakan sebuah relasi yang hidup dan dinamis, persatuan dan persekutuan yang vital. Hal ini menunjukkan Bapa dan Kristus merupakan subjek yang berbeda. Selanjutnya dalam kisah pembaptisan Yesus yang menyatakan ketiga Pribadi. Di mana Roh Kudus turun seperti burung merpati dan diam dia atas Yesus, sementara suara Bapa terdengar dari surga menyatakan Yesus sebagai Anak-Nya yang terkasih. Dan sekali lagi ini memberikan indikasi tiga pribadi yang berbeda. Bahkan pada kesempatan yang 
lain, Yesus juga pernah berujar bahwa Dia adalah jalan kepada Bapa (Yoh. 14:6 dst.). Ungkapan Yesus ini hendak menegaskan bahwa orang yang melihat Dia sama saja telah melihat Bapa. Yesus begitu identik dengan sekaligus berdistingsi dari Bapa.

Dengan demikian, bukti dalam kitab Injil (belum termasuk dalam suratsurat yang lain) sudah cukup membuktikan bahwa kristologi Kristen mengajarkan tentang inkarnasi dan sekaligus trinitas, di mana Yesus merupakan Pribadi kedua yang secara substansi adalah Allah bersama dengan Bapa dan Roh Kudus, namun pada waktu yang bersamaan merupakan ketiga pribadi yang berbeda. Sekali lagi ajaran kristologi Kristen menolak dan meruntuhkan kristologi Islam yang sama sekali menegasi ajaran inkarnasi dan trinitas.

\section{KESIMPULAN}

Setelah melalui proses penelitian yang panjang, maka berikut ini dikemukakan beberapa kesimpulan sebagai hasil kajian dan evaluasi terhadap ajaran Kristologi dalam Islam.

Pertama, ajaran kristologi dalam Islam tidak bersumber dari Alkitab atau lebih tepatnya didasarkan kepada kesaksian Alquran. Itulah sebabnya, tidak dapat dipungkiri bahwa kristologi Islam sangat bertolak belakang dengan kristologi dalam kekristenan yang berdasarkan Alkitab. Kristologi Islam mengajarkan Yesus bukan Allah, Yesus tidak pernah mati, Yesus tidak pernah bangkit, Yesus hanyalah nabi, Yesus menghabiskan sisa hidup dan mati di India, menolak ajaran Trinitas dan inkarnasi, dan istilah Anak Allah dipahami secara keliru. 
Kedua, kristologi dalam Islam mengalami kegagalan dalam merumuskan sebuah konsep kristologi yang benar karena justru menggunakan Alquran sebagai sumber informasi. Padahal Alquran memiliki informasi yang keliru tentang Kristologi bahkan bukanlah merupakan sumber informasi yang valid untuk belajar kristologi. Itulah sebabnya, sebagai evaluasi terhadapa kristologi Islam adalah kristologi jenis ini merupakan kristologi yang keliru bahkan sesat karena tidak alkitabiah.

Ketiga, kristologi yang benar adalah kristologi yang alkitabiah. Kristologi ini adalah kristologi yang mengajarkan bahwa Yesus adalah Allah, Anak Allah yang merupakan pribadi kedua dalam Allah Tritunggal. Selain itu, Kristologi alkitabiah juga mengajarkan bahwa Yesus benar-benar telah mati dan benar-benar telah bangkit untuk memberikan keselamatan bagi manusia yang berdosa. Selain itu, Alkitab juga mengajarkan bahwa Yesus yang adalah Allah telah berinkarnasi menjadi manusia.

Dengan demikian, kristologi dalam Islam merupakan kristologi yang sesat sehingga tidak dapat dijadikan referensi untuk belajar dan berbicara tentang Kristus.

\section{DAFTAR PUSTAKA}

Arifin, Bey. 1983. Dialog Islam Dan Kristen. Surabaya: Fa. Pustaka Progressif.

Beeke, Joel R. 2020. Apakah Kebangkitan Itu? Surabaya: Momentum.

Evans, William B. 2020. Apakah Inkarnasi Itu? Surabaya: Momentum.

Fanani, Ahwan. n.d. "Kristologi Islam Dan Reformulasi Dialog Islam-Kristen Di Indonesia." Abied's Site.

Grudem, Wayne. 1994. Systematic Theology: An Introduction to Bible Doctrine. 
Patterson Avenue S.E., Grand Rapids, Michigan, USA: Zondervan Publishing House.

Köstenberger, Andreas J. 2009. A Theology John's Gospel and Letters: The Word, the Christ, the Son of God. GrandRapids, Michigan: Eerdmans Publishing.

Letham, Robert. 2011. Allah Trinitas: Dalam Alkitab, Sejarah, Theologi, Dan Penyembahan. Surabaya: Momentum.

McGrath, Alister E. 1997. Studies in Doctrine. Grand Rapids, Michigan: Zondervan Publishing House.

Michaels, J Ramsey. 2010. The Gospel of John (The New International Commentary on the New Testament). Mchigan: Eerdmans Publishing Company.

Moleong, Lexi J. 2010. Metodologi Penelitian Kualitatif. Revisi. Bandung: PT Remaja Rosdakarya.

"Pentingnya Belajar Kristologi." 2019. Masroor Library. 2019.

Peterson, Robert A. 2018. Keselamatan Yang Dikerjakan Oleh Sang Anak: Karya Kristus. Surabaya: Momentum.

Putra, Adi. 2019. "PRA-EKSISTENSI YESUS BERDASARKAN BUKTIBUKTI INJIL YOHANES.” DIDACHE 1 (1): 94-102.

Salim, Kodiran. 2012. "Belajar Kristologi Damai Bagi Umat Islam." Http://Jaktim.Muhammadiyah.or.Id/Id/Artikel-Belajar-Krostologi-DamaiBagi-Umat-Islam--Detail-136.Html. 2012.

Stott, John R.W. 2015. Salib Kristus. Surabaya: Momentum.

Suntani, Djuyoto. 2001. Yesus Penganut Islam. Gresik: Putra Pelajar.

Syarqawy, Dr. M. Abdullah. 1994. Yesus Dalam Pandangan Al-Ghazali: Analisa Pemikir Besar Islam Tentang Dogma Trinitas. Bukittinggi: Pustaka Da'i.

Troll, Christian W. 2013. Muslim Bertanya Kristen Menjawab. Jakarta: PT Elex Media Komputindo (Kompas Gramedia).

Waryono, Waryono. 2011. "Beberapa Problem Teologis Antara Islam Dan Kristen.” ESENSIA: Jurnal Ilmu-Ilmu Ushuluddin 12 (1): 97-118. https://doi.org/10.14421/esensia.v12i1.704.

Wibowo, Wahju S. 2012. "Kristologi Dalam Konteks Islam Di Indonesia.” Gema Teologikal: 1-11. 